\title{
Theoretical Philosophy and Philosophy of Science in Soviet Times: Some Remarks on the Example of Estonia, 1960-1990
}

\author{
Rein Vihalemm ${ }^{\dagger}$ \\ Department of Philosophy, University of Tartu
}

The discusses the area of Soviet philosophy that roughly corresponds to theoretical philosophy and philosophy of science based on the example of Estonia and proceeding from the University of Tartu. The period from approximately 1960 to 1990 , when the author himself was engaged in the field, is under focus. The aim of the paper is not to provide an overview of individual philosophers during the time, or of their works, but to give a more general description of the philosophy of the Soviet era. Soviet and East European philosophy of the time has received rather little critical treatment in English-language literature. However, a few general overviews trying to prove that this legacy is worth studying have been published. The paper is focused on the question of which kinds of philosophical research it was possible to conduct under the abnormal conditions of the time and whether some starting points and problems of this research might still be viable today. Estonian experience confirms the general conclusion of those authors who, analyzing the legacy of Marxism, have found that although Marxism is generally not considered a serious philosophy nowadays, but rather an ideological basis of a failed political doctrine, it has nevertheless something to offer when treated in a more depoliticized manner, in the general context of philosophical inquiry.

Keywords: dialectical materialism, dialectics, Soviet philosophy, Fundamental Question of Philosophy, practice, "Foreword Marxism", "ontologists", "epistemologists"

\section{Introduction}

In this paper, I will discuss-based on the example of Estonia and proceeding from the University of Tartu-the area of Soviet philosophy that corre-

Corresponding author's address: Rein Vihalemm, Department of Philosophy, Institute of Philosophy and Semiotics, University of Tartu, 18 Ülikooli, 50090 Tartu, Estonia. Email: rein.vihalemm@ut.ee.

$\nmid$ Rein Vihalemm died on 18th of July 2015. 
sponds approximately to theoretical philosophy and the philosophy of science, ${ }^{1}$ concentrating on the period of approximately 1960-1990, when I myself was engaged in the field; that is to say, the period before 1960 will not be included. The aim of this paper is not to provide an overview of individual philosophers in Estonia during the time, or of their works, but to give a more general description of the philosophy of the Soviet era. Soviet and East European philosophy of the time has received rather little critical treatment in English-language literature. In my opinion, it would be sensible to proceed from the point that "the philosophical legacy of the defunct USSR (and the other Soviet bloc nations) should not be left for dead without a serious salvaging operation to assess what it did and did not accomplish and to preserve what was valuable in it" (Dumain 2001). A few general overviews trying to prove that this Soviet and East European philosophical legacy is worth studying have nevertheless been published. The best-known of them is (Scanlan 1985), ${ }^{2}$ and of later ones (Bakhurst 1991; Taras 1992; Zweerde 1997). The most recognized general work on Soviet philosophy of science is (Graham 1987); a more general account of the first 100 years of the development of Marxism as a philosophy of science, i.e. from the mid-1840s until the mid-1940s, is (Sheehan 1993). ${ }^{3}$ I will give a brief overview of the nomenclature of philosophy of the time, and touch upon the more characteristic tendencies and problems (e.g. the dispute between the "epistemologists" and the "ontologists") in Soviet philosophy. Above all, I am interested in what kind of philosophical investigations it was possible to pursue at the time and whether some starting points and problems in them might also be viable today. Some of the more explicit questions will include the following:

\footnotetext{
1 A survey of the philosophy of science in Estonia including the Soviet period was published in (Vihalemm 2001a) and read at the 2oth Baltic Conference on the History of Science in Tartu (Vihalemm 2001b); at the 22nd Baltic Conference on the History of Science in Vilnius, a paper was presented which concerned the development of the philosophy of science in Soviet Estonia, focussing on the conception of the practical nature of science (Vihalemm 2006). The Soviet period was also analysed earlier, among others in (Vihalemm and Müürsepp 2007). Earlier versions of the present paper were read at the 4th Annual Conference of Estonian Philosophy: The Roots and Offshoots of Estonian Philosophy (5-7 June, 2008, University of Tartu) and at the 23rd International Baltic Conference on the History of Science in Riga (Vihalemm 2008).

2 "Scanlan was willing to concede that there was genuine philosophy to be found under the rubric of Marxism, with the implication that it was genuinely philosophical in spite of the Marxism which it was required to adhere to officially" (Dumain 2003).

3 It is worth noting Helena Sheehan's-who has "tried to look at it [Marxism] freshly, neither as apologist nor as prosecutor, but someone who could recognize it as a formidable intellectual tradition and at the same time be free to subject it to critical assessment" (Sheehan 1993, xi)—evaluation: "Marxism may be rejected, but it has not been refuted. It still needs to be seriously studied and critically considered" (Sheehan 1993, xvi).
} 
- Was the practice of the ritual (so to speak) of proceeding from Marxism - "Foreword Marxism" - the only way of doing real research work, or was it also possible to proceed from Marx's theories in terms of content?

- Would it be possible to develop a philosophy proceeding from Marx's and Engels's philosophy of the time to some extent today, or should it be forgotten completely?

- Do Marx's "Theses on Feuerbach" only have certain historical importance?

- Would it be justified to speak about "the great basic question of all philosophy" in some form even today, as it was done in Engels's formulations at that time?

- What about the Marxist idea of the unity of ontology, logic, and the theory of knowledge?

- Should we agree with Loren R. Graham's evaluation from 1987: "Contemporary Soviet dialectical materialism is an impressive intellectual achievement" (Graham 1987, 429)?

\section{The general situation}

Looking at the Soviet classification system of philosophy, it is possible to obtain from the Internet resources of VAK ${ }^{4}$ (Higher Evaluation Commission) classifications and changes in the following picture:

Philosophy in the Soviet Union, code 09.00.00

09.00.01 Dialectical and historical materialism

09.00.02 Theory of scientific socialism and communism

09.00.03 History of philosophy

09.00.04 Aesthetics

09.00.05 Ethics

09.00.06 Scientific atheism, religion (history and present time)

09.00.07 Logic

09.00.08 Philosophical problems of natural science

09.00.09 Concrete sociological investigations [during some period] ${ }^{5}$

09.00.10 Philosophical problems of politics [emerged during some period]

${ }^{4}$ http://www.ccas.ru/isir/vak.htm

5 http://www.vusnet.ru/biblio/archive/novikova_hirsc/ec5.aspx 
The counterparts to theoretical philosophy and philosophy of science were therefore a part of 09.00.01 Dialectical materialism, 09.00.07 Logic, and 09.00.08 Philosophical problems of natural science, as well as, of course, 09.00.03 History of philosophy.

Incidentally, the present situation in Russia appears to be as follows: ${ }^{6}$

Philosophy in the Russian Federation, code 09.00.00

09.00.01 Ontology and theory of knowledge

09.00.03 History of philosophy

09.00.04 Aesthetics

09.00.05 Ethics

09.00.07 Logic

09.00.08 Philosophy of science and technology

09.00.11 Social philosophy

09.00.13 History of religion (religiovedenie), philosophical anthropology, philosophy of culture

Philosophy in Soviet Estonia has already been described by Eero Loone in his articles published in Estonian in 1993 and 2002 (Loone, 1993; 2002). I will initially make use of some of his observations here. If we consider the existence of a sufficient number of philosophers as a criterion, then we should admit that Estonian philosophy of science and Estonian philosophy in general was born in Soviet Estonia. Prior to that, there had been no more than four philosophers simultaneously active in Estonia. ${ }^{7}$ Of course, in Soviet Estonia the conditions for philosophy were abnormal: Soviet-style Marxism was compulsory in philosophy; direct links with Western philosophy were blocked; and Soviet philosophy was regarded as a mainly ideological and propagandistic discipline. But the need for philosophers was great as (Marxist) philosophy was a required course for all specialities at all universities. There were more than 60 full time positions for philosophers in Estonia, although not all of them were occupied by philosophers in the real sense of the word. The main question is: how is it possible to practice philosophy in a non-liberal culture and in a situation where the obligatory philosophy is that of Marxism-Leninism, which represents the "philosophy of fundamental authority" (Loone 1993b, 133-134)?

By the late-1950s, but even more so by the early-196os, the philosophy of science became the central research area, since it provided more freedom of research than any other area. Loone has come up with the striking description "Foreword Philosophy" (Loone 1993b, 136) or, to be more exact,

${ }^{6}$ http://db.informika.ru/cgi-bin/vak/q2.plx?key1=09

7 Cf.: (Loone 1993b, 313-132); see also (Loone 1993a, 18-19). 
"Foreword Marxism" (an expression of his that I have also used in several papers already): the foreword and the concluding remarks presented the obligatory viewpoints of Marxism-Leninism, and appropriate quotations were scattered throughout the text, but substantially one could practice almost normal research. Another reason why philosophy of science became the most widespread field of philosophy was that philosophy could not be studied as a speciality at university in Estonia, but it was possible to do so in the post-graduate programme after specializing in some other area.

In Tartu State University, the orientation towards the philosophy and methodology of science was also a deliberate choice made by Rector Feodor Klement (1903-1973), who came from Leningrad ${ }^{8}$ and was the rector from 1951-1970. Klement's substantial role in developing the methodology and philosophy of science in Estonia in the Soviet times has already been emphasized (Remmel and Kaevats 1987). As will be expanded upon subsequently, in Soviet philosophy the so-called "ontologist" viewpoint was widespread, meaning basically the reanimation of speculative natural philosophy (in the sense of Naturphilosophie). According to this, Soviet dialectical materialism was considered a general theory of nature with which the sciences had to come into line. Klement understood that Soviet science, like theoretical biology, cybernetics, quantum mechanics and relativity physics suffered notably from a lack of philosophical-methodological education and that the teaching staff of philosophy did not have sufficient scientific preparation. $\mathrm{He}$ therefore aimed to develop methodology of science and to prepare philosophers with basic education in science. In Klement's sphere of influence, there appeared broadly speaking three main trends: (A) general methodological problems of scientific knowledge, (B) philosophy and methodology of exact sciences (especially of physics, but also of chemistry), and (C) philosophy and methodology of biology. ${ }^{9}$ In (Remmel and Kaevats 1987, 138) this has been illustrated by a diagram, where the arrows indicate important teacherstudent relationships and the lines, relationships between colleagues that influenced each other's research work to a notable extent. I present the diagram here with my own amendments and specifications (Fig. 1).

${ }^{8}$ Saint Petersburg's official name, 1924-1991.

9 As stated already, the present article is not concentrating on the description of individual authors and their works. See an overview of the Soviet Estonian philosophy of science in (Vihalemm and Müürsepp 2007, 167-169, 172-174, and also a bibliography of the main works by authors mentioned, pp.183-191). 


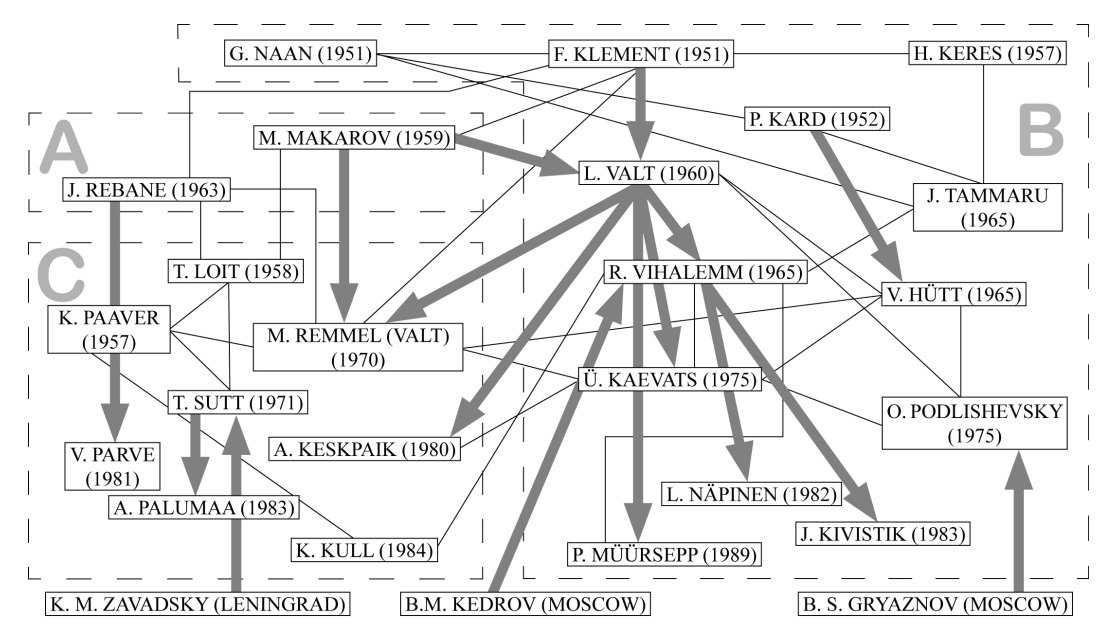

Fig. 1. The orientation towards methodology of science was initiated by the Rector of the University of Tartu (1951-1970), Feodor Klement (1903-1973). The arrows indicate important teacher-student relationships and the lines, relationships between colleagues that influenced each other's research work to a notable extent. A - general methodological problems of scientific knowledge; $B$ - philosophy and methodology of exact sciences; $C$ - philosophy and methodology of biology. The dates added refer to the publication year of the author's first work in the field of philosophy and methodology.

It should also be mentioned that the University established (with the full support of the Rector), among others, contact (in 1963) with a leading Soviet philosopher and historian of science, Bonifati Kedrov (1903-1985); ${ }^{10}$ from 1962 to 1973 he was the head of the Institute of the History of Natural Sciences and Technology at the USSR Academy of Sciences; in 1973-1974, he was the head of the Institute of Philosophy. Kedrov was opposed to "ontologists" (whom I will return to soon). In 1963, an important (for Soviet philosophy) work was published: The Unity of Dialectics, Logic and the Theory of Knowledge. It emphasized that according to V. I. Lenin the purpose of Marxist philosophy, especially in the case of the philosophical problems of natural sciences, was to elaborate dialectically the history of natural sciences and technology. ${ }^{11}$ But what was actually essentially important: instead of the

${ }^{10}$ Kedrov's background was in chemistry. He also became the supervisor of my Candidate's $(\mathrm{PhD})$ Thesis on the philosophy of chemistry.

${ }^{11}$ V. I. Lenin's notes from his Philosophical Notebooks were emphasized by Kedrov: "In Capital, Marx applied to a single science logic, dialectics and the theory of knowledge of materialism [three words are not needed: it is one and the same thing]..." (Lenin 1895-1916, Plan of Hegel's Dialectics); "Continuation of the work of Hegel and Marx must consist in the dialectical elaboration of the history of human thought, science and technology" (Lenin 
"ontological" approach-being speculative-scholastic or merely summarizing scientific results in a popularizing manner, i.e., by using "the method of examples" - the need to research philosophically the history of science was emphasized.

Methodological seminars that were held within the so-called party (i.e. the Communist Party of the USSR) educational system ${ }^{12}$ in research institutions also played a significant role. Despite the form of ideological work, philosophical-methodological problems of a research area were sometimes discussed in a rather serious manner in such institutions.

\section{About the atmosphere of the research in philosophy of science}

It was Lembit Valt (1934-2008), then a lecturer at Tartu University, later a professor of Tallinn University, who laid the foundation for studies in the methodology of science in Estonia. Valt came to philosophy from physics. His work from the 196os and 1970s about modelling and thought experiments was widely known. It was of great importance that Klement and Valt initiated an all-Union conference Method of modelling in natural science in Tartu in 1966, being basically the first conference on modelling held in the USSR and thus crucial in the development of methodology of science. The participants were 43 philosophers and scientists from all over the Soviet Union. (The collection of abstracts, printed in 400 copies, was widely used and quoted, and it quickly became an item of great value and a bibliographical rarity: Tezisy 1966.) Valt claimed that it was the second conference of this field in the world (the first was held in Utrecht, Holland in 1960). The ideological background of the event was later analyzed by Valt (1994): the participants involved an "ideologically suspicious element" and he was reproached by the party institutions as there was no "model" in Marx's vocabulary and the whole topic was ideologically suspicious; among other things, he also wrote that the collection of presentations remained unpublished. His own monograph that was published two years later in Russian-The cognitive importance of thought models in physics (in the Russian-language series Proceedings in Philosophy of Transactions of Tartu State University: Valt

\footnotetext{
1895-1916, Conspectus of Hegel's book The Science of Logic, Book Two: Essence, Sect. I).

${ }^{12}$ This party educational system was a multi-stage political-educational network of Soviet propaganda. The highest level of this system consisted of the Marxism-Leninism evening university and theoretical (methodological) seminars. Lecturing in these evening courses was a duty of university lecturers of Marxist disciplines, philosophy among them, and the university lecturers and the researchers of scientific research institutes were obliged to attend. However, in theoretical seminars that had to be organized according to areas of speciality in scientific research institutions and in universities, the researchers mainly concentrated on issues of methodology of science within the framework of their own area of speciality, while these issues were supposed to proceed from Marxist-Leninist philosophy.
} 
1964) - some copies of which were already circulating, was destroyed, on the grounds that for some reason it had not been edited. Valt retrospectively thought that this, too, happened in connection with the ideological accusations directed at the conference on modelling. Hence, such things happened even during the mid-196os.

Ideological accusations were rather common later as well. For example, while working on an analysis of Thomas Kuhn's works, I was accused in 1982 (in connection with the submission of an article to the USSR central philosophical journal Voprosy filosofii (Problems of Philosophy)) of the tendency of preferring Kuhnianism over Marxism. The head of the chair (department) of philosophy of Tartu University (1971-1986), Professor Jaan Rebane, also considered it necessary to emphasize that Kuhn was, after all, a relativist-reactionary (he had found-or someone had drawn his attention to-an article "The Scientific Outlook-Under Attack" in the US Communist Party journal Political Affairs: Pappademos and Lumpkin 1974). But any such reproaches could be blocked by reference to Lenin, who said that a distinction must be made between the philosophical/ideological and the scientific. ${ }^{13}$ Kuhn includes a lot of issues belonging to the history of science as a scientific discipline on its own, and not to philosophy. Lenin had criticized those overzealous party soldiers who were not able to evaluate or make use of scientific results. Science was valued highly and therefore it was still possible to engage oneself in the philosophy of science as well (however, the name 'philosophy of science' was not officially in use ${ }^{14}$ ).

${ }^{13}$ See (Lenin 1908-1909, 6.1): "Not a single one of these professors, who are capable of making very valuable contributions in the special fields of chemistry, history, or physics, can be trusted one iota when it comes to philosophy. Why? For the same reason that not a single professor of political economy, who may be capable of very valuable contributions in the field of factual and specialized investigations, can be trusted one iota when it comes to the general theory of political economy. For in modern society the latter is as much a partisan science as is epistemology." So the digression from Marxism as the general theory was not allowed, but the possibility still remained to emphasize that Kuhn's possible "very valuable contributions in the field of factual and specialized investigations" cannot be ignored, either, but must be researched very seriously.

${ }^{14}$ According to the official- "dictionaryish"-view, dialectical materialism "is the only possible source of the philosophical ideas and methodological principles" of science and its emergence "essentially was the culminating point in the historical process by which philosophy became a separate science" which is a developing science. "Every major discovery in natural science and the changes in social life serve to concretize and develop the principles and propositions of D. M. [dialectical materialism], which absorbs the new scientific evidence and the historical experience of mankind" (Rosenthal and Yudin 1967, 276). In this context-see also the classification of the so-called philosophical sciences in the Soviet Union discussed previously (p. 3)-philosophical problems of natural science was accepted as a research area, presuming the cooperation of natural scientists and philosophers; and, though not as a separate area, methodology of science was also accepted, referring to 
There were, however, problems with science (as there still are!) concerning the question of what a "proper" science actually is. In contrast to the present, however, the ideological aspect of the question was of great importance at the time: one could speak about scientificity while occupying the Marxist position. The official standpoint was that it was Marxism that made sociology, history and also philosophy a science. (I once happened to say at the Marxism-Leninism evening university that philosophy is not a science, which caused a lot of trouble.) I had and still have a difference of opinion with my colleague Eero Loone on, for example, the issue of the scientificity of historical research. Loone thinks that history can be and in the future also will be considered a science similar to, e.g., physics. ${ }^{15}$ I, however, see a principled difference between these two. Although Marx and Engels emphasized the scientificity of history and sociology (above all, in opposing their materialist standpoints to earlier idealist ones, while Marx compared, e.g., in the preface to Das Kapital his method of research to that of natural science and declared that the ultimate aim of his work was "to lay bare the economic law of motion of modern society" Marx 1867), the concept of science in their time was much vaguer than it is now. Therefore, Marx and Engels were convinced that science will reach a higher theoretical level only when it, in addition to using mathematics, it also starts to think dialectically and to become a historical cognition. They express their opinion at the start of the The German Ideology (1845): "We know only a single science, the science of history. One can look at history from two sides and divide it into the history of nature and the history of men. The two sides are, however, inseparable; the history of nature and the history of men are dependent on each other so long as men exist." I had an academic discussion on this issue with Loone. ${ }^{16}$ But at the time, we had to be careful so that our ideas could not be considered non-Marxist, not to mention, anti-Marxist, which would have resulted in ideological accusations and possible loss of job. Therefore, it was necessary for both of us to emphasize that we were developing classical Marxist viewpoints and proceeding strictly from these. Our viewpoints had to be based on corresponding references and quotations (and we both man-

the analysis of the scientist's work-both on the philosophical and also special science level-"for elucidating the components that are the means of gaining scientific knowledge, the very conditions and prerequisites of it. Science as a system giving rise to scientific knowledge-such is the subject of methodological analysis" (Lektorski and Shvyrev 1972, 10).

${ }^{15}$ For instance, he tried to scientifically, including the means of graph theory, to provide a more formalized and stricter rationale and specification of Marx's theory of socioeconomic formations (Loone 1983) and to investigate Marxism from the point of view of analytical philosophy of history (Loone 1992).

${ }^{16}$ See, e.g., (Loone 1982, 22-23), (Vihalemm 1979a), (Vihalemm 1983b). 
aged to find them!). And I still think, so to speak, together with Marx, that I was right, and I am sure that Loone is of the same opinion about himself. ${ }^{17}$

However, Western literature was becoming, though with great difficulties, more and more available and some contacts opened up ${ }^{18}$ and among other things researchers managed to take part in some international conferences (the first one was probably the 4th International Congress of Logic, Methodology and Philosophy of Science in 1971, held in Bucharest, Romania -that is, in a socialist country-where the Estonian participants were Hütt, Kard, and Valt; a few Estonian philosophers of science also participated in the next LMPS congresses).

\section{4. “Ontologists" and "epistemologists." What is Dialectics?}

But what was the general situation in the Soviet philosophy of science and dialectical materialism like? I have characterized it already in my earlier works. Roughly speaking, for a long time the central issue was the relationship between philosophy or dialectical materialism or materialist dialectics-as it was named more exactly-and the natural sciences. There were "ontologists" and "epistemologists." The point was that in the Soviet philosophy of science (or, as it was called, the philosophical problems of natural sciences), but also in dialectical materialism, in the 1950 and continuing into the $1960-$ '7os, the common view was that dialectical materialism, the Soviet version of Marxist philosophy, was a general science of nature (as historical materialism was a general theory of society) that generalized the results of the natural sciences, shaping them into a general dialectical system of nature. Such an approach-being actually, as mentioned above, an attempt to reanimate, in a party-ideological context, the natural philosophical (in the sense of Naturphilosophie) approach-was called "ontological." This gave philosophy the right and even the obligation to intervene in the sciences in order "to help" them to function according to the principles of dialectical materialism and to criticize the results that were not compatible with it. Therefore, initially the main task of Estonian philosophy of science was not so much

${ }^{17}$ In a 1994 paper (Loone 1994, 57), he notes that he has treated history "as a research that lacks the exclusive contradistinction of 'sciences' . [... ] The word 'science' has usually been used widely, similarly to the German word 'Wissenschaft', which conceptually coincides with F. P. Ramsey's conception of 'knowledge"' I, however, have tried to study (in my works, referred to in footnote 16 , and in later works) just the specificity of physics-like science as science in a narrower sense and to show that the character of historical cognition and knowledge is different to it, i.e. non-scientific (if by 'science' we mean 'physics-like science').

${ }^{18}$ For example, Valt, working on the aforementioned problems with modelling, developed, as he himself puts it (Valt 1994, 48), correspondence with Mary Hesse, Rom Harré, and Ernest H. Hutten. 
discussing real philosophical problems, but protecting science and its history from (pseudo)philosophy. ${ }^{19}$ Genuinely philosophical problems were reached when researchers took a clearly methodological and epistemological position, became acquainted with Western literature on the philosophy of science, and considered, in one way or another, the methods and criteria characteristic of it. ${ }^{20}$ As mentioned already, a limited number of direct contacts opened up as well. The controversy between the "epistemologists" and the "ontologists" was a major controversy in Soviet philosophy of science. ${ }^{21}$

One should mention that some Estonian scientists and philosophers of

${ }^{19}$ See also, e.g., (Graham 1987, 20-23, 58-61, 100, 153, 314-317, 351, 407, 435, 422) and the references to Estonian authors in it. In this connection, it should also be mentioned that not "only the Soviet philosophers are responsible for introducing Marxism into science, while the Soviet scientists supposedly ignore Marxism. Quite a few Soviet scientists have defended the position that dialectical laws are visible in nature, a position that at least some of the professional philosophers find embarrassing" (Graham 1987, 317). For instance: "[T]he dispute between the ontologists and the epistemologists that was going on elsewhere in Soviet science was invisible here [in the philosophy of chemistry] also. It is interesting to notice that philosophers like Frolov, Garkovenko, and Vihalemm tended to support the nonintrusive epistemological view, while chemists like Korovin, Zhdanov, and apparently Koptiug sided with the ontologists" (Graham 1987, 317).

${ }^{20}$ Here it is necessary to note the following which is pointed out by, e.g., Helena Sheehan $(1993,2)$ : "The consensus undoubtedly is that the main dramatis personae of nineteenthand twentieth-century philosophy of science are such as Mach, Carnap, Popper, Kuhn, Lakatos, Feyerabend. This line of development has constituted the point of reference to which all commentators are expected to orient themselves, no matter how fundamental their criticisms of it, no matter how deep their commitment to charting a new way forward. I do not doubt that this line of development has been vitally important one and that anyone working in this discipline without a thorough knowledge of the history of its major shifts and its present-day twists and turns would deserve harsh judgements from his or her colleagues. My point, however, is to call attention to the fact, too often neglected in this milieu, that this is not the only major line of development in nineteenth- and twentiethcentury philosophy of science. Another line of development, stemming from the very bold and original work of Marx, and Engels, has been one with very different relationship to both philosophy and science, but with, nevertheless, its own full-blown tradition in philosophy of science..." And she emphasizes that it has always seemed "somewhat ironic" to her "that the most influential line of development in breaking with classical empiricism in the direction of more contextual, sociohistorical, metaphysical view of science has come via Wittgenstein and Kuhn, when there were earlier bodies of thought already there, which had long since put forward far deeper and more radical critiques of the received view of science and far richer alternative versions. Both the radical empiricist tradition of James and Dewey and the dialectical materialist tradition of generations of Marxists have embodied alternative versions of empiricism (in the sense of seeing the origins of knowledge in experience), which were based on much richer notions of experience, which allowed the metaphysical and historical dimensions of knowledge to come more fully into play. Both rejected the formalist, individualist, particularist, passivist model of knowledge in favour of a more historicist, social, contextualist, activist model" (Sheehan 1993, 4).

${ }^{21}$ See, e. g., (Graham 1987). 
science already managed to protect science against pseudo-philosophy in the early 1950s. It was Gustav Naan who, from an "ontological" position, defended the theories of relativity, which were considered specimens of backward "physical idealism" in the USSR at that time (Naan 1951). ${ }^{22}$ He was supported in his efforts by the physicist Paul Kard (1952). The same can be said about protecting genetics against Lysenkoism (see, e. g., a historical overview: Valt 1994). These initiatives were bold deeds at the time, but could hardly be more than just a description of the scientific theories meant for philosophers (see also: Graham 1987, 354-363).

A more theoretical-philosophical question was: what is to be understood as dialectics? This was supposed to be the science of the most general laws of nature, society and the development of thought. According to Engels:

Thus dialectics reduced itself to the science of the general laws of motion, both of the external world and of human thought-two sets of laws which are identical in substance, but differ in their expression in so far as the human mind can apply them consciously, while in nature and also up to now for the most part in human history, these laws assert themselves unconsciously [...]. Thereby the dialectic of concepts itself became merely the conscious reflex of the dialectical motion of the real world and thus the dialectic of Hegel was turned over; or rather, turned off its head, on which it was standing, and placed upon its feet. And this materialist dialectic [...] has been our best working tool and our sharpest weapon...(Engels 1886, ch. IV)

The opposition of dialectical and metaphysical ${ }^{23}$ methods of investigation and thought can be schematically summarized as follows:

\section{DIALECTICAL}

- all-around

- unity and intertwining of opposites

\section{METAPHYSICAL}

- one-sided

- denial of the unity of opposites

('thinking in clear, unmediated oppositions: the speech includes yes, yes and no, no and anything beyond that is seen as excess')

${ }^{22}$ Incidentally, in his paper Naan (1948) himself decries non-Soviet interpretations of relativity physics as "physical idealism."

${ }^{23}$ This term is used here in the sense of "[ $t$ ] he old method of investigation and thought which Hegel calls "metaphysical”... (Engels 1886, ch. IV). 
- the world is not a collection of isolated, ready-made things, but a system of their connection with the vast whole, processes, movements; is changing and developing, historical
- non-historical; sees only things in isolation, apart from their connection with the vast whole, not processes, movements, development

This understanding of dialectics (as a method of thought and investigation) comprehending the real world, "things and their representations, ideas, in their essential connection, concatenation, motion, origin, and ending" (Engels 1877, Introduction) is also connected with, as it were, the general theoretical problem, namely the issue of the coincidence of ontology, theory of knowledge and $\operatorname{logic}^{24}$ in dialectics (that has already been referred to), and, finally, the question of the end of philosophy, ${ }^{25}$ which was not a favoured issue during the Soviet times. Estonian philosophers, too, treated these issues differently, although the viewpoints of the Marxist classics seemed to be fairly clear. For instance, the coincidence of ontology, epistemology and logic in dialectics is touched upon by M. Makarov (head of the chair (department) of philosophy at the University of Tartu, 1960-1966 and 1968-

${ }^{24}$ 'Logic' here naturally does not refer to general or formal logic which abstracts itself from the content, but substantive logic which examines the development of knowledge, not abstracting itself from the content. Hegel was the first to open up-though in an idealistic, mystical manner-this kind of logic in his Science of Logic. Dialectics as logic, "as an investigation and discipline distinct from formal logic, deals with categories-and so studies and distinguishes modes of abstraction and assembly of abstractions" (Cornforth 1967, part III, 2.3). According to materialist dialectics: "To work out the laws of thought is to work out the principles in accordance with which we must think in order to inform our practice" (Cornforth 1967, part III, 2.5).

25 “... [T] he Marxist conception of history [...] puts .... an end to philosophy in the realm of history, just as the dialectical conception of nature made all natural philosophy both unnecceray and impossible. It is no longer a question anywhere of inventing interconnections from out of our brains, but to discovering them in the facts. For philosophy, which has been expelled from nature and history, there remains only the realm of pure thought (so far as it is left): the theory of the laws of the thought-process itself, logic and dialectics" (Engels 1886). Or, e.g., in Anti-Dühring: "What still independently survives of all former philosophy is the science of thought and its laws-formal logic and dialectics. Everything else is merged in the positive science of nature and history" (Engels 1877, Introduction); "This modern materialism [i.e. materialist dialectics], the negation of the negation, is not the mere re-establishment of the old, but adds to the permanent foundations of this old materialism the whole thought-content of two thousand years of development of philosophy and natural science, as well as of the history of these two thousand years. It is no longer a philosophy at all, but simply a world outlook which has to establish its validity and be applied not in a science of sciences standing apart, but in the real sciences. Philosophy is therefore "sublated" here, that is, "both overcome and preserved" $\{D$. K. G. 503\}; overcome as regards its form, and preserved as regards its real content" (Engels 1877, part I, ch. 13). 
1971) in his book Categories of materialist dialectics (Makarov 1973, 12-14), where he writes that dialectics cannot be identified with epistemology in an absolute sense because this would mean either ontologizing epistemology (which would lead to idealism as seen by Schelling and Hegel) or a positivist separation of philosophy from the methodology of science. It is the latter that Makarov sees as the denial of philosophy as ontology. Makarov interprets ontology as world outlook (the world outlook function of materialist dialectics): the system of views, concepts, and notions about the surrounding world and man's place in it. I recall disputes between Estonian colleagues. That brings us to the concept of practice.

\section{Marxist conception of practice}

I would like to emphasize that besides practicing "Foreword Marxism," one could also really proceed from Marxist ideas, ${ }^{26}$ first of all from the conception of practice. This conception can be seen as the origin of several approaches also in contemporary philosophy of science in which the practical, being simultaneously social and historical, nature of science is acknowledged, empiricism is criticized and scientific realism is defended.

There were different interpretations of this Marxist conception in Soviet as well as in Western philosophy. It should be mentioned that in, so to speak, official Soviet philosophy the notion of practice was used as a criterion of truth only, and not as a new fundamental principle in philosophy in general, a new treatment of the very reality, which was in nuce represented in Marx's critical "Theses on Feuerbach". Let me quote here an extract from the first and second theses (Marx 1845):

The main defect of all hitherto-existing materialism-that of Feuerbach included-is that the Object [der Gegenstand], actuality, sensuousness, are conceived only in the form of the object [Objekt], or of contemplation [Anschauung], but not as human sensuous activity, practice [Praxis], not subjectively. Hence it happened that the active side, in opposition to materialism, was developed by idealism-but only abstractly, since, of course, idealism does not know real, sensuous activity as such. Feuerbach wants sensuous objects [Objekte],

\footnotetext{
${ }^{26}$ See also footnote 20 . In connection with that footnote, it is also appropriate to mention that, e.g., a collective work by Estonian philosophers of science (Vihalemm 1979b) includes an overview of the history of philosophy of science in which special attention is paid to the views of R. Carnap, K. R. Popper, I. Lakatos and T. S. Kuhn, emphasizing at the same time that many initial points in the postpositivist philosophy of science and in the criticism of neopositivism have been characteristic of Marxist treatment from the beginning and that the criticism of empiricism in post-positivist approaches is mainly incomplete.
} 
differentiated from thought-objects, but he does not conceive human activity itself as objective [gegenständliche] activity. [...]

2

The question whether objective truth can be attributed to human thinking is not a question of theory but is a practical question. Man must prove the truth, i.e., the reality and power, the this-sidedness [Diesseitigkeit] of his thinking, in practice. The dispute over the reality or non-reality of thinking which is isolated from practice is a purely scholastic question.

One could refer also, for instance, to Marx's words from the "Economic and Philosophical Manuscripts of 1844" (XXXIII): "But nature too, taken abstractly, for itself-nature fixed in isolation from man-is nothing for man."

Engels writes in Dialectics of Nature (1883, Notes and Fragments, Dialectics, B):

Natural science, like philosophy, has hitherto entirely neglected the influence of activity on their thought; both know only nature on the one hand and thought on the other. But it is precisely the alteration of nature by men, not solely nature as such, which is most essential and immediate basis of human thought, and it is in the measure that man has learned to change nature that his intelligence has increased.

There was (and still is) a trend in Western Marxism of refusing to talk about nature as an ontological category at all. So-called revisionists, such as Alfred Schmidt from the Frankfurt school or Yugoslav philosophers from the Praxis group, argued that Marx's materialism is non-ontological and that Lenin's conception of "reflection" between world and consciousness should be replaced by the concept of "Praxis" as the basic category of epistemology. These ideas of "practical materialism" seem also to have a close connection to the pragmatist philosophy which-as it was understood-tries to give a description of man's knowledge-seeking without using concepts of man-independent reality and truth as correspondence with reality, replacing it with the requirement that knowledge has to have a suitable kind of correspondence with practice. ${ }^{27}$ Thus it is little wonder that the Marxian conception of practice, especially written as Praxis, seemed to be quite dangerous for Soviet philosophy.

However, though consistent, proceeding from the conception of practice in the philosophy of science and in epistemology was actually considered

\footnotetext{
${ }^{27}$ According to Sidney Hook-one of the pragmatist authors who was known as an expert on Marx's philosophy and was himself a Marxist at the beginning of his career-it is "the philosophy of experimental naturalism" which can be regarded "as a continuation of what is soundest and most fruitful in Marx's philosophical outlook upon the world" (Hook 1976, $1)$.
} 
heretical in the Soviet Union, as it appeared (as we saw) to undermine the official dialectical materialist doctrine of scientific knowledge and especially Leninist reflection or copy-theory in epistemology as its essential part. ${ }^{28}$ It was still possible to elaborate these "heretical" ideas if one managed to show that they did not really retreat from Marxist-Leninist philosophy. ${ }^{29}$

Certain versions of the conception of the practical nature of science were developed in Estonia. ${ }^{30}$ For instance, the post-positivist historical approach in philosophy of science, especially Kuhn's ideas, or criticism of classical science and Ilya Prigogine's views on non-classical science were interpreted in this context. ${ }^{31}$ The critique of classical science by Prigogine with his coauthor Isabelle Stengers was shown to be similar to Marx's critique of the understanding of the world, reality, only in the form of the object or contemplation, but not as human sensuous activity, practice, not subjectively (see above: Marx's first thesis on Feuerbach). And the conception of new, nonclassical science was shown to be from the philosophical viewpoint in a sense close to the Marxist approach. ${ }^{32}$ The classical view of science and of scientific objectivity is paradoxical: it is subjective objectivity. The objective scientific picture of the world is constructed by the subject (the scientist) according to special criteria of scientificity and by prescribing special conditions of cognition. In the scientific world picture, the world is regarded as a subject-free object which is described from outside as if the describer did not belong to

${ }^{28}$ Lenin's simplistic reflection theory of cognition was outlined in his Materialism and Empirio-Criticism, which was used as the supreme philosophical text of the Soviet regime; his Philosophical Notebooks were, so to speak, more dialectical and Marxist.

${ }^{29}$ A characteristic example of this was the occasion described in (Alexeyev 1995, 460-461) by the historian and methodologist of physics, Vladimir Vizgin in his memoirs about the physicist and philosopher Igor Alexeyev (1935-1988), who, proceeding from Marx's first thesis on Feuerbach, developed a concept that he called "subjective materialism." Vizgin recalls a discussion about allowing Alexeyev's doctoral thesis, The Conception of Complementarity: An Historical and Methodological Analysis (later published as a monograph: Alexeyev 1978) to be defended in the Institute of the History of Natural Sciences and Technology at the USSR Academy of Sciences. After the applicant for the degree had finished his speech, B. M. Kedrov-who, at the time, was the head of the Institute's Department of Philosophy-presented a solid stack of volumes of the classics of Marxism and, referring to these in turn, started to indicate a certain divergence of the author of the thesis from the principles of dialectical materialism. The applicant then responded by presenting an equally large stack of books and, by also referring methodically to the classics, proving no less convincingly his adherence to the Marxist-Leninist philosophy (this is also shown in the last chapter of the monograph referred to-especially in \$2: "An attempt at dialectical materialist interpretation of the conception of complementarity"). The thesis was approved for defence.

${ }^{30}$ See, e.g., monograph by seven authors compiled by R. Vihalemm (1979b), referred to in footnote 26 .

${ }^{31}$ See, e.g., (Vihalemm 1980, 1981, 1982, 1983a).

${ }^{32}$ See, e.g., (Vihalemm and Näpinen 1986, 1987). 
it. This view is illusory, of course, if it is understood as the objectively true picture of the world (nature) itself.

As far as Kuhn's approach is concerned, it is worth mentioning that the idea of the practical nature of science was in fact one of the cornerstones of Kuhn's account. I agree, for instance, with the American philosopher of science Joseph Rouse, who has recently published several works on the practical nature of science (Rouse 1987, ch.2, Rouse 1996, 2002, 2003), writing among other things:

The most influential attempt to consider science as a field of practices rather than a network of statements, Thomas Kuhn's The Structure of Scientific Revolutions, has also been perhaps the most misunderstood. In particular, the depth of his criticism of representationalist epistemology has often been overlooked. (Rouse 1987, 26)

On the other hand Rouse is also right that "Kuhn has been strongly influenced by the epistemological tradition he challenges" (Rouse 1987, 27) and therefore should be taken "further in the direction of an account of science as practice than he himself would be happy with" (Rouse 1987, 27).

I would like to stress that several varieties of realism developed by philosophers of science, such as, Bhaskar's (1978) scientific realism, Wartofsky's (1979) historical epistemology, Chalmers' (1982) non-representative realism, Hacking's (1983) experimental realism, Harré's (1986) referential realism, and Giere's (1988) constructive realism are to my mind close to what one might call a version of practical realism in the philosophy of science, i.e., accounts which stress the practical nature of science. ${ }^{33}$ And if one wants, one can find similarities or some kind of origins for them in the Marxist conception of practice. Bhaskar, Wartofsky, Rouse and Chalmers have also referred to Marx. I mean that, broadly speaking, a sort of practical realism is an alternative to traditional (naïve or metaphysical) realism, internal realism, instrumentalism (and pragmatism, more generally ${ }^{34}$ ), and social constructivism.

${ }^{33}$ In Soviet philosophy of science, the practical nature of science was-in addition to I. S. Alexeyev referred to in footnote 29 -especially emphasized by V. S. Stepin (Stepin and Tomilchik 1970, Stepin 1976). Estonian philosophers of science had good, cooperative relations with him (as well as with I. S. Alexeyev). Vyacheslav Semyonovich Stepin is a leading Russian philosopher of science, and from 1988 to the present, Director of the Institute of Philosophy of the Academy of Sciences of the USSR (now the Russian Academy of Sciences). His monograph Theoretical Knowledge (Moscow: Gardariki, 200o), which summarizes the results of more than twenty years of research-based on the Marxist conception of historical practice-of the structure and dynamics of scientific theoretical knowledge has been now published also in English as (Stepin 2005; see also Nugayev 2007).

${ }^{34}$ Pragmatism is often characterized as instrumentalism in the sense that it holds the principle "meaning is use" concerning language only in a cultural context. It should be observed, however (see, e.g., Määttänen 2002, 212), that such a characterization underestimates the 


\section{6. "The great basic question of all philosophy"}

Soviet philosophy was characterized among other things by strict procedure from the Fundamental Question of Philosophy (F.Q.P., for short) formulated by Engels. Engels's wording of the F.Q.P. is the following:

The great basic question of all philosophy, especially of more recent philosophy, is that concerning the relation of thinking and being. [...]

[T] he question: which is primary, spirit or nature-that question, in relation to the church, was sharpened into this: Did God create the world or has the world been in existence eternally?

The answers which the philosophers gave to this question split them into two great camps. Those who asserted the primacy of spirit to nature and, therefore, in the last instance, assumed world creation in some form or other-and among the philosophers, Hegel, for example, this creation often becomes still more intricate and impossible than in Christianity - comprised the camp of idealism. The others, who regarded nature as primary, belong to the various schools of materialism.

These two expressions, idealism and materialism, originally signify nothing else but this; and here too they are not used in any other sense.

But the question of the relation of thinking and being had yet another side: in what relation do our thoughts about the world surrounding us stand to this world itself? Is our thinking capable of the cognition of the real world? Are we able in our ideas and notions of the real world to produce a correct reflection of reality? In philosophical language this question is called the question of identity of thinking and being, and the overwhelming majority of philosophers give an affirmative answer to this question. (Engels 1886, ch. 2)

In connection with the epistemological side of the F.Q.P., Engels further writes:

[T] here is yet a set of different philosophers-those who question the possibility of any cognition, or at least of an exhaustive cognition, of

role of experimental practice and "prevents from solving the controversy between scientific realism and methodological instrumentalism of what is real. Another consequence is a common misinterpretation of John Dewey's operational conception of knowledge as a form of instrumentalism according to which theoretical terms do not refer but are mere instruments for interpreting and predicting observations. These problems can be solved if the connection between theory and reality is analyzed as a relation through interaction which consists observation and action (experimentation)." Sami Pihlström has also shown that pragmatism can be interpreted as a variety of realism-pragmatic realism (Pihlström 1996). Unfortunately, he does not discuss the analogies between Marxism and pragmatism in that text. 
the world. To them, among the more modern ones, belong Hume and Kant, and they played a very important role in philosophical development. [...] The most telling refutation of this as of all other philosophical crotchets is practice-namely, experiment and industry. If we are able to prove the correctness of our conception of a natural process by making it ourselves, bringing it into being out of its conditions and making it serve our own purposes into the bargain, then there is an end to the Kantian ungraspable "thing-in-itself." The chemical substances produced in the bodies of plants and animals remained just such "things-in-themselves" until organic chemistry began to produce them one after another, whereupon the "thingin-itself" became a thing for us-as, for instance, alizarin, the coloring matter of the madder, which we no longer trouble to grow in the madder roots in the field, but produce much more cheaply and simply from coal tar. (Engels 1886, ch. 2)

These standpoints of Engels were interpreted (and are interpreted) in several ways. In the official Soviet philosophy, they were canonical, strictly to be followed in order not to digress from the "only and true" dialectical materialism that was considered the scientific world outlook. ${ }^{35}$ But trying to be a philosopher and not an ideologist in the Soviet system, it was possible to discuss and apply these formulations of Engels of Marxist philosophy in the context of more general interpretation, where the issues mentioned above arose, concerning the ontologists' and the epistemologists' positions, the rendering of the Marxist view on materialist dialectics corresponded to the principle of the coincidence of ontology, epistemology and logic in dialectics and to the "heretical" in the Soviet philosophy position based on Marx's conception of practice as the fundamental principle of philosophy. The view of Engels, quoted above, that materialist dialectics as modern materialism "is no longer a philosophy at all, but simply a world outlook which has to establish its validity and be applied not in a science of sciences standing apart, but in the real sciences" and "[f]or philosophy, which has been expelled from nature and history, there remains only the realm of pure thought," was rather "heretical" for official Soviet philosophy that attempted to introduce a canonical approach, as it actually left opportunities for doing the real, i.e., so to speak, non-canonical philosophical research. Neither did the canonical approach approve of Marx and Engels's statement at the start of The German Ideology: "The premises from which we begin are not arbitrary ones, not dogmas, but real premises from which abstraction can only be made in

35 See, e.g., A Dictionary of Philosophy (Rosenthal and Yudin 1967, 343): “... a scientific formulation of the F.Q.P. makes it possible consistently to apply the principle of partisanship of philosophy, strictly to delimit and counterpose materialism and idealism and resolutely to uphold the scientific world outlook of dialectical materialism." 
the imagination. They are the real individuals, their activity and the material conditions under which they live... These premises can thus be verified in a purely empirical way." So it was necessary to acknowledge the dialectical materialist solution of the F.Q.P. and to criticize idealist, dualist, and agnostic approaches, as well as the metaphysical (non-dialectical) approach which, according to the dialectical materialist view, led to the former three approaches. However, within the framework of these approaches, it was possible to discuss a number of issues starting with what this materialism is after all. ${ }^{36}$ What problems does the materialism-thesis solve? What is dialectic? What is the task of philosophy? Why and how have the idealist, dualist, and agnostic views emerged? What is scientific knowledge? And so on. It can be said that in the framework of the F.Q.P.--even when acknowledging its dialectical materialist solution-most of the essential philosophical problems can be presented and discussed.

Hereby I wish to draw attention to the fact that in Western philosophical works parallels can also be found to the F.Q.P. formulated in Marxist philosophy, as well as to the Marxist standpoint about the end of philosophy as metaphysical ontology and much more. In this case I am not referring to the so-called positive references in non-Marxist works to Marxist authors that can also be found ${ }^{37}$ (although very seldom lately), but to analog-

${ }^{36}$ In addition to the aforementioned, Engels (1886) could also be quoted here, indicating how the understanding of materialist dialectics as a science-based modern materialism based on his views gives rise to this question. In chapter II, Engels emphasizes that "... the materialism .... is a general world outlook resting upon a definite conception of the relation between matter and mind. [...] With each epoch-making discovery even in the sphere of natural science, it has to change its form; and after history was also subjected to materialistic treatment, a new avenue of development has opened here, too"; and in chapter IV, referring to Marx, he summarizes: "The separation from Hegelian philosophy was here also the result of a return to the materialist standpoint. That means it was resolved to comprehend the real world-nature and history—just as it presents itself to everyone who approaches it free from preconceived idealist crotchets. It was decided mercilessly to sacrifice every idealist fancy which could not be brought into harmony with the facts conceived in their own and not in a fantastic interconnection. And materialism means nothing more than this. But here the materialistic world outlook was taken really seriously for the first time and was carried through consistently-at least in its basic features-in all domains of knowledge concerned."

${ }^{37}$ Perhaps the best known of them is Heidegger's reference to Marx in connection with the question of the end of philosophy (Heidegger 1977); in the philosophy of science and epistemology there are quite often references to Engels's (1886) criticism of Kantian agnosticism (see, e.g., Niiniluoto 1999, 275). The rather widespread use of Marx's conception of practice as a fundamental philosophical principle has already been commented upon. Here we might also add Activity Theory, which initially was a result of developing psychology based on Marxist philosophy by the Russian psychologists L. S. Vygotsky (1866-1934), S. L. Rubinshtein (1889-1960), A. R. Luria (1902-1977) and A. N. Leontiev (1903-1979). "Nowadays, Activity Theory is not an exclusively Russian approach. Recent developments 
ical viewpoints to the Marxist approach in non-Marxist Western philosophy, which should indicate that Marxist philosophy-that is nowadays unfortunately not considered a serious philosophy, but rather an ideological basis of a failed political doctrine-can also be treated in the general context of philosophical inquiry and that in this context it has quite something to offer. It could also be said that several Marxist standpoints have been, as it were, rediscovered (as indicated above). I will confine myself to only one example here.

Let us compare the formulation of F.Q.P. above and the standpoint of Engels with the insistence that "the human world/physical universe problem is the fundamental problem of philosophy" in (Maxwell 2001, 18). The first chapter of the cited work is entitled "The Human World/Physical Universe Problem" (Maxwell 2001, 1-20), and it also contains a section with the heading "Fundamental Problem of Philosophy" (Maxwell 2001, 3-6). Here are some quotations from (Maxwell 2001):

... the central, fundamental problem of modern philosophy ... is generated ... by the birth of modern science, and acceptance of the view of the universe associated with modern science. The ancestry of the problem goes farther back than that, at least to Democritus in the fourth century B.C.; but that is because Democritus held a view of the universe-atomism - that is close to the sort of view of the universe upheld, in one form or another, by those most closely associated with the creation of modern science. (Maxwell 2001, 3)

If Cartesian dualism is adopted, and everything that physics leaves out is, as it were, removed from the external world and put into our Cartesian minds, then the human world/physical universe problem does more or less reduce to the problem of the relationship between mind and brain. We should not, however, at the outset just assume that Cartesian dualism is correct, especially as it is not correct. [...]

$[\mathrm{T}]$ he fundamental problem has as much to do with what the nature of physical is, as what the nature of the mental is. (Maxwell 2001, 5-6)

As we can see, this is an obvious parallel to the F.Q.P formulated in Marxist philosophy. There are actually even more similar traits to Marxist philosophy in Maxwell's works, although he does not proceed from that approach and he makes only a few references to Marx, these being mainly of a critical nature. A more profound treatment of Maxwell's philosophy remains beyond the scope of the present article.

in Activity Theory are associated with a larger research community which also includes researchers from Finland, Germany, Denmark, the USA, and other countries. There are also attempts to expand the coverage of Activity Theory beyond a purely psychological realm towards more general socially-and organizationally-oriented problems in understanding the dynamics of work activities" (Bannon 1997); see, e.g, (Engeström et al. 1999). 


\section{7. "But Marxism is not just an inventory of phrases, it is a philos- ophy"}

As mentioned above-and this has been emphasized by many Western authors writing about Marxist philosophy (in addition to the ones mentioned earlier, see, e.g., Groisman 2007)-Marxism is nowadays (not to mention how it existed in the Soviet regime) unfortunately not considered a serious philosophy, but rather an ideological basis of a failed political doctrine. It is, however, important to try to treat it in a more de-politicized manner, in the general context of philosophical inquiry, where it has something to offer. It is true not only of Soviet philosophical writings, but often also of the writings of Marxist authors in the West, that they reflect "the fact that philosophy has party lines [and] that different party lines don't always get on with each other" and the Marxist party line must always be brought out clearly and followed strictly (Feyerabend 1977, 372). The heading of the present section is a quotation from Paul Feyerabend's comment on the Australian Marxist philosophers' J. Curthoys and W. Suchting's voluminous review-article of his Against Method (Curthoys and Suchting 1977), where Feyerabend gives his critics an ironic and reproachful response to the following of the strict party line, which is characteristic of many Marxist authors, yet unhelpful for philosophical debate:

One must admit, our two southern rhapsodists have studied the Marxist vocabulary well. They are not too original and there are certainly better stylists even among contemporary Marxists. Still, they know the right words and they know how to put them together. But Marxism is not just an inventory of phrases, it is a philosophy and it demands from its practitioners a little more than a pure heart, strong lungs, and a good memory. It demands from them the ability to recognize an opponent, to separate him from other, though related opponents, it demands a nose for differences that might seem insignificant when compared with the 'great questions of the time'... (Feyerabend 1977, 373)

Unfortunately, everything concerning following the party line often holds true not only for Marxists, but also for their anti-Marxist critics. One of the most typical examples here is Karl Popper's well-known paper "What is dialectic?", first delivered in 1937 and republished as a chapter of his frequently reprinted book (2002, 419-451), on which, e.g., in quite a recent article (Groisman 2007) - the author of which is, incidentally, a theoretical physicist, which might give reason to suppose that there is no following of any party lines in philosophy - the following has been said:

Ironically, Popper's view that all Marxist dialecticians dogmatically dismiss any criticism of dialectic by claiming that their opponents do 
not understand dialectic makes his position no less dogmatic. Indeed, any attempt to criticise Popper's views on dialectics would be seen only as an additional example of responses by "dogmatic dialecticians," making his theory essentially immune. This completely prevents dialecticians from being able to criticize Popper's views. This is exactly the opposite of what the great philosopher wanted. Therefore, for the sake of "antidogmatic science" it is desirable and even necessary to defend dialectic. (Groisman 2007, 1)

The aim of this work was to reassess the relevance of Popper's criticism of the applicability of the dialectical approach to the development of scientific theories and scientific thought. I have presented and discussed the main points of Popper's criticism of dialectic and have concluded that it is unsound. I argued that Popper has significantly contributed to the link that was unfortunately created between dialectical materialism as a philosophical-scientific system and communist ideology. The latter found itself misused by several totalitarian regimes. Popper politicized dialectic helping to build prejudices against it. In the interest of anti-dogmatic science these prejudices should be dissolved. Thus, this work is an attempt to rehabilitate dialectic by addressing Popper's original criticism. (Groisman 2007, 10)

Both Popper's article and his anti-Marxism in general received detailed criticism from the renowned British Marxist philosopher Maurice Cornforth $^{38}$ (see his 1968), who also analyzed linguistic philosophy (as is widely known, in the early-1930s he was a follower of Wittgenstein) (Cornforth 1967) from a Marxist position. His works were also published in Russian translation in the Soviet Union. Many Estonian philosophers thought highly of these. Although Cornforth, being the official ideologist of the Communist Party of Great Britain, also followed the Marxist party line-we were used to taking it as a ritual-, his approach, especially in the two books mentioned, was a lot fresher compared to the official Soviet philosophers, as it truly proceeded from the philosophical essence of the Marxist classics and

${ }^{38}$ Of course, he is not the only critic of Popper, although he may well be the most competent and profound among the Marxists. Popper was in his youth a Marxist and a Communist, meaning that by criticizing Marxism he was also criticizing himself, as if he found it necessary to confess, e.g., in his preface to the Russian translation of his The Open Society and its Enemies (Popper 1992, 7). His criticism of Marxism as a system of views forming the basis of the ideology and practice of the Communist movement is, of course, striking and essential. But, on the other hand, his criticism of Marxism, following the, so to speak, anti-Marxist party line, is partly philosophically and methodologically superficial and on several points groundless, as has been pointed out by several Western philosophers, both Marxists (see, e.g., the refutation of Popper's view that Marxism is a "historicism" and is deterministic in Suchting 1972) and non-Marxists (e.g., in (Johanson 1975, 114-117) it is shown that Popper only apparently rejects Marx's theory with the help of the methodological rules established by himself). 
developed it in the context of the newest developments in philosophy (Cornforth has already been referred to and quoted in footnote 24, above). As he himself wrote in the Foreword to Second Edition of his (1967) (this bookalong with (Cornforth 1968) - is probably not so well-known, and the reader hopefully will not mind me including some characteristic quotations from these books):

This book sets out to criticize one branch of contemporary philosophy from the point of view of Marxism. At the same time its aim is to discuss what can be learned from this philosophy. The Marxist standpoint which I try to maintain against all comers is not a stationary one, since Marxist ideas must always be developing and be formulated for our own times and problems. That is why as much as a third of this book deals with Marxism itself ... I have been criticized for putting all this in about Marxism, as irrelevant to the critical purpose of the book. But it was essential to my purpose. For I do not think one should separate criticism of other views from development of one's own. [...] To conclude, I am well aware that some of the propositions I have advanced in this book may not be very readily acceptable to many of my fellow-Marxists. For one thing, some of them are new; and whatever is new raises queries and needs to be scrutinized carefully. For another, some go contrary to traditionally accepted interpretations of Marxism. I do not believe for a moment that all I have put forward on these questions is yet correctly formulated in this book. A lot more work needs to be done. I think, however, that this discussion can contribute to the creative development of Marxist theory in its application to contemporary problems.

Several Estonian philosophers of science considered especially compelling and coincidental with our own views (e.g., in the abovementioned monograph by seven authors compiled by Vihalemm 1979b) Cornforth's treatment of so-called laws of dialectics in both of his books referred to above. Among other things, we found in it some support for the criticism of the "ontologists"' position, discussed previously. Cornforth in his time emphasized in principle the same things as today more radically, e.g., the modern theoretician of Marxism, Bertell Ollman (2003, 12):

With all misinterpretation conveyed about dialectics, it may be useful to start by saying what it is not. Dialectics is not a rock-ribbed triad of thesis-antithesis-synthesis that serves as an all-purpose explanation; nor does it provide a formula that enables us to prove or predict anything; nor is it the motor force of history. The dialectic, as such, explains nothing, proves nothing, predicts nothing and causes nothing to happen. Rather, dialectics is a way of thinking that brings into focus the full range of changes and interactions that occur in the world. As part of this, it includes how to organize a reality viewed 
on this manner to purpose of study and how to present the results of what one finds to others, most of whom do not think dialectically.

Cornforth called attention to how to understand the Marxist standpoint concerning the end of philosophy as some kind of independent general "theory" or "science," so that of all former philosophy there remains only "the realm of pure thought," the theory or science "of the laws of thought-process itself, logic and dialectics" and "everything else is merged in the positive science of nature and history." What are these laws of thought which are also laws of materialist dialectics? ${ }^{39}$ Cornforth-who, as mentioned above, emphasized dialectics as logic distinct from formal logic_-deals with categories, i.e. studies and distinguishes modes of abstraction and the assembly of abstractions. According to materialist dialectics, the laws of thought are the principles in accordance with which we must think in order to inform our practice. Materialist dialectics should be construed as a metatheory:

There is theory in the sense of theory which informs or claims to inform practice; and theory in the sense of statement of principles to be employed in informing practice. Scientific theories, religious theories, and also many traditional philosophical theories, are the first sort. But the theory of dialectical materialism is of the second sort. (Cornforth 1968, 97)

...principles of materialism and dialectics are distinguished from statements of empirical sciences and from theorems of logic and mathematics, precisely by their logical type and practical function. In them is discovered the correct form for philosophical, as distinct from empirical, formal-logical or mathematical statements. [...] To formulate and establish valid philosophical principles we must engage in that type of abstraction and generalization which results in categorystatements. And to establish that these statements are genuine it must be shown that they are necessary in the formulation and assembly of genuine information. (Cornforth 1968, 115, 120)

In (Cornforth 1967, III, 2.4) it is elucidated that when Engels in the Dialectics of Nature called the laws of dialectics "the most general laws" which were abstracted from nature and human society, then

if he meant, or is interpreted as meaning, that laws of dialectics are comparable with, say, laws of motion as formulated by Newton or Einstein, differing only in being even more general, then that simply exemplifies confusion in the use of the words "law" and "general" (admittedly very confusing words), since the latter are empirical laws and the former are not. There is not a shred of evidence to suggest that Engels was actually guilty of any such confusion-that he really

\footnotetext{
${ }^{39}$ See above (pp. 205-206 and footnote 25) for quotations from (Engels 1886, 1877).
} 
thought that, for example, the "law of transformation of quantity into quality" was a transformation law of the same logical type as, say, the first law of thermodynamics. Some of his interpreters did afterwards perpetrate such confusion-but Engels himself simply did not deal with such logical questions, which had not yet been raised at the time he was writing. The point can, if one likes, be put like this-that the difference between these laws is not only a quantitative difference, of degree of generality, but a qualitative difference; they are different kinds of law, or exemplify different uses of the word "law."

Perhaps the difference can be most perspicaciously brought out in terms of Dr Popper's criterion for a "scientific" (or empirical) law. Such a law, he said, must be falsifiable. Sure enough, the laws of thermodynamics, for example, are falsifiable, even though never actually falsified. But principles or laws concerning categories, including "the most general" ones, or universal "laws of dialectics," are not falsifiable-or if they are, they are not correctly formulated. [...] Correctly formulated principles concerning category, or "category propositions," are such that their breach results in "absurdity"-and this is the test of such principles.

The "absurdity," or "category mistake," or uninformativeness means in Marxist philosophy that a proposition is formulated which in principle cannot be tested in practice (cf., e.g., Vihalemm 1979b, 58-59, 167-170, 211).

\section{Conclusion}

If we were, by way of a summary, to try to answer the sample questions formulated in the introduction, then the short answers would be:

(1) The practice of "Foreword Marxism" was not the only way of doing real research work in philosophy in Soviet times; it was also possible to proceed genuinely from Marx's ideas, especially and first of all from the conception of practice;

(2) It is possible to develop the philosophy emerging from Marx's and Engels's works to some extent today;

(3) Marx's "Theses on Feuerbach" are not only historically importantthey remain topical today as well;

(4) It is justified even today to speak in some form about "the great basic question of all philosophy," as was done in Engels's formulations at that time; i.e., in a sense, it is still justified to speak about the question of the relationship of thinking to being, examined from two (so to speak, ontological and epistemological) aspects; 
(5) The Marxist idea of the unity of ontology, logic, and the theory of knowledge is not completely outdated, because any attempt to speak about an ontology separately from, as it were, category logic and epistemology cannot be successfully defended;

(6) Considering whether we should agree with Loren R. Graham's evaluation-"Contemporary Soviet dialectical materialism is an impressive intellectual achievement"-my opinion is that in answering this question a clear distinction must be made between what there is in Soviet dialectical materialism that has really been achieved due to Soviet-style Marxist philosophy-and there could hardly be anything in this sense that constitutes an impressive intellectual achievement (unless this evaluation is understood ironically) - and what has been achieved despite the supremacy of Soviet-style Marxismin this sense there are, indeed, several achievements-whether by practicing "Foreword Marxism" or proceeding from the, so to speak, authentic academic Marxism and developing it in the modern context.

\section{Acknowledgements}

I would like to thank my colleague Paul McLaughlin for linguistic revision of the paper. The research was supported by the Estonian Science Foundation grant No. 7946.

\section{Bibliography}

Alexeyev, I. S. (1978). The Conception of Complementarity: An Historical and Methodological Analysis [in Russian] = Алексеев И. С. Концепция дополнительности: историко-методологический анализ, Наука, Москва.

Alexeyev, I. S. (1995). The Activity Conception of Cognition and Reality: Selected Works on Methodology and Philosophy of Physics [with the bibliography of Works and memories about him] [in Russian] = Алексеев И. С. Деятельностная концепция познания и реальности. Избранные труды по методологии физики (с библоиграфией трудов и воспоминания о нем), Руссо, Москва.

Bakhurst, D. (1991). Consciousness and Revolution in Soviet Philosophy: From the Bolsheviks to Evald Ilyenkov, Cambridge University Press, Cambridge. 
Bannon, L. (1997). Activity theory.

URL: $\quad$ http://www.irit.fr/ACTIVITES/GRIC/cotcos/pjs/ TheoreticalApproaches/Actvity/ActivitypaperBannon.htm

Bhaskar, R. (1978). A Realist Theory of Science, The Harvester Press, Sussex.

Chalmers, A. F. (1982). What is this thing called Science? An assessment of the nature and status of science and its methods, Open University Press, Milton Keynes and Philadelphia.

Cornforth, M. (1967). Marxism and the Linguistic Philosophy, Lawrence \& Wishart, London.

Cornforth, M. (1968). The Open Philosophy and the Open Society: A Reply to Dr. Popper's Refutation of Marxism, Lawrence \& Wishart, London.

Curthoys, J. and Suchting, W. (1977). Feyerabend's discourse against method: A Marxist critique, Inquiry 20: 243-371.

Dumain, R. (2001). Salvaging Soviet philosophy (1).

URL: http://www.autodidactproject.org/bib/ussrphil.html

Dumain, R. (2003). Soviet historiography of philosophy: Review essay.

URL: http://www.autodidactproject.org/my/sovphilhist.html

Engels, F. (1877). Anti-Dühring.

URL: $h t t p: / / w w w . m a r x i s t s . o r g / a r c h i v e / m a r x / w o r k s / 1877 / a n t i-d u h r i n g /$

Engels, F. (1883). Dialectics of Nature.

URL: http://marxists.anu.edu.au/archive/marx/works/1883/don/cho7c.htm

Engels, F. (1886). Ludwig Feuerbach and the Outcome of Classical German Philosophy.

URL: http://www.marxists.org/archive/marx/works/download/Marx _ Ludwig_Feurbach_and_the_End_of_German_Classical_Philosop.pdf

Engeström, Y., Miettinen, R. and Punamäki, R.-L. (eds) (1999). Perspectives on Activity Theory, Cambridge University Press, Cambridge.

Feyerabend, P. (1977). Marxist fairytales from Australia, Inquiry 20: 372-397.

Giere, R. N. (1988). Explaining Science: A Cognitive Approach, The University of Chicago Press, Chicago.

Graham, L. R. (1987). Science, Philosophy and Human Behavior in the Soviet Union, Columbia University Press, New York.

Groisman, B. (2007). What is dialectic? Some remarks on Popper's criticism.

URL: http://philsci-archive.pitt.edu/3980/1/What_is_Dialectic_110408. pdf

Hacking, I. (1983). Representing and Intervening, Cambridge University 
Press, Cambridge.

Harré, R. (1986). Varieties of Realism: A Rationale for the Natural Sciences, Basil Blackwell Ltd, Oxford.

Heidegger, M. (1977). The end of philosophy and the task of thinking, in D. F. Krell (ed.), Basic Writings, Harper and Row, New York, pp. 373-392.

Hook, S. (1976). From Hegel to Marx: Studies in the Intellectual Development of Karl Marx, The University of Michigan Press, Ann Arbor.

Johanson, I. (1975). A Critique of Karl Popper's Methodology, Akademiförlaget, Lund.

Kard, P. (1952). About the theory of relativity [in Russian] = Кард П. О теории относительности, Bопросы философии 5: 240-247.

Kedrov, B. M. (1963). The Unity of Dialectics, Logic and the Theory of Knowledge [in Russian] = Кедров Б. М. Единство диалектики, логики и теории познания, Госполитиздат, Москва.

Lektorski, V. A. and Shvyrev, V. S. (1972). Methodological analysis of science (the types and levels) [in Russian] = Лекторский В. А., Швырев B. С. Методологический анализ науки (типы и уровни), Филособия, методология, наука, Наука, Москва.

Lenin, V. I. (1895-1916). Philosophical Notebooks, Vol. 38 of Collected Works. URL: http://www.marxists.org/archive/lenin/works/cw/volume38.htm

Lenin, V. I. (1908-1909). Materialism and Empirio-Criticism, Vol. 14 of Collected Works.

URL: http://www.marxists.org/archive/lenin/works/cw/volume14.htm

Loone, E. (1982). Philosophical problems of historical science [in Russian] = Лооне Э. Философские проблемы исторической науки, Tartu Ülikooli toimetised. Töid filosoofia alalt 599: 3-26.

Loone, E. (1983). The Theory of Socio-Economic Formations [in Estonian] = Ühiskondlik-majanduslike formatsioonide teooria, Eesti Raamat, Tallinn.

Loone, E. (1992). Soviet Marxism and Analytical Philosophies of History, Verso, London.

Loone, E. (1993a). Between West and East: The case of philosophy in Estonia, in K. Siilivask (ed.), 17th Baltic Conference on History of Science: Baltic science between the West and the East, Tartu University Press, Tartu, pp. 18-20.

Loone, E. (1993b). Estonian philosophy on the boundary between East and West [in Estonian] = Eesti filosoofia ida ja lääne piiril, Studia Philosophica 1: $129-155$. 
Loone, E. (1994). The rise and decay of the Estonian philosophy of history [in Estonian] = Eesti ajaloofilosoofia tõus ja hääbumine, in R. Vihalemm et al. (ed.), Teadusfilosoofia ja teadusmetodoloogia Eestis: olukord ja perspektiivid, Teaduslugu ja nüüdisaeg IX, TTEÜ ja TÜ filosoofia osakond, Tallinn, pp. 53-62.

Määttänen, P. (2002). Experimental practice and the problem of realism, in E. Alvarez, R. Bosch and L. Villamil (eds), Volume of Abstracts. 12th International Congress of Logic, Methodology and Philosophy of Science, Departemento de Filosofia. Universidad de Oviedo, Oviedo, pp. 212-213.

Makarov, M. (1973). Categories of Materialist Dialectics [in Estonian] $=\mathrm{Ma}-$ terialistliku dialektika kategooriad, 2nd edn, Eesti Raamat, Tallinn.

Marx, K. (1845). Theses on Feuerbach.

URL: http://www.marxists.org/archive/marx/works/1845/theses/index.htm

Marx, K. (1867). Preface to the first German edition, Capital, Vol. 1.

URL: http://www.marxists.org/archive/marx/works/1867-c1/p1.htm

Maxwell, N. (2001). The Human World in the Physical Universe: Consciousness, Free Will, and Evolution, Rowman \& Littlefield Publishers, Inc.

Naan, G. (1948). Contemporary 'physical' idealism in the USA and England at the service of clergy and reaction [in Russian] = Наан Г. Современный “физический” идеализм в США и Англии на службе поповщины и реакции, Вопросы филособии 2: 287-308.

Naan, G. (1951). On the question of the principle of relativity in physics [in Russian] = Наан Г. К вопросу о принципе относительности в физике, Вопросы философии 2: 57-77.

Niiniluoto, I. (1999). Critical Scientific Realism, Oxford University Press, New York.

Nugayev, R. (2007). A leading paradigm of modern Russian philosophy of science, Journal for General Philosohy of Science 38: 403-406.

Ollman, B. (2003). Dance of the Dialectic: Steps in Marx's Method, University of Illinois Press.

Pappademos, J. and Lumpkin, B. (1974). The scientific outlook-Under attack, Political Affairs 11.

Pihlström, S. (1996). Structuring the World: The Issue of Realism and the Nature of Ontological Problems in Classical and Contemporary Pragmatism, Societas Philosophica Fennica, Helsinki.

Popper, K. (1992). A letter to my Russian readers [in Russian] = Поппер K. Письмо моим русским читателем, Открытое общество и его враги, 
Феникс, Москва.

Popper, K. (2002). Conjectures and Refutations: The Growth of Scientific Knowledge, Routledge Classics, London.

Remmel, M. and Kaevats, Ü. (1987). On the role of the methodology of science in the history of science of the Estonian SSR [in Estonian] = Teadusmetodoloogia osast Eesti NSV teadusloos, Teaduslugu ja nüüdisaeg IV, Valgus, Tallinn, pp. 137-148.

Rosenthal, M. and Yudin, P. (1967). A Dictionary of Philosophy, Progress Publishers, Moscow.

Rouse, J. (1987). Knowledge and Power: Toward a Political Philosophy of Science, Cornell University Press, Ithaca.

Rouse, J. (1996). Engaging Science: How to Understand Its Practices Philosophically, Cornell University Press, Ithaca.

Rouse, J. (2002). How Scientific Practices Matter: Reclaiming Philosophical Naturalism, The University of Chicago Press, Chicago.

Rouse, J. (2003). Kuhn's philosophy of scientific practice, in T. Nickles (ed.), Thomas Kuhn, Cambridge University Press, Cambridge.

Scanlan, J. (1985). Marxism in the USSR: A Critical Survey of Current Soviet Thought, Cornell University Press, Ithaca.

Sheehan, H. (1993). Marxism and the Philosophy of Science: A Critical History, Humanities Press International, Atlantic Highlands.

Stepin, V. S. (1976). Becoming of Scientific Theory: Substantial Aspects of Construction and Genesis of Theoretical Knowledge of Physics [in Russian] = Степин В. С. Становление научной теории. Содержательные аспекты строения и генезиса теоретических знаний физики, Издательство БГУ им. В. И. Ленина, Минск.

Stepin, V. S. (2005). Theoretical Knowledge, Springer, Dordrecht.

Stepin, V. S. and Tomilchik, L. M. (1970). The Practical Nature of Cognition and Methodological Problems of Contemporary Physics [in Russian] = Степин В. С., Томильчик Л. М. Практическая природа познания и методологические проблемы современной физики, Наука и техника, Минск.

Suchting, W. A. (1972). Marx, Popper and 'historicism', Inquiry 15: 235-266.

Taras, R. (ed.) (1992). The Road to Disillusion: From Critical Marxism to Postcommunism in Eastern Europe, M. E. Sharpe, Inc., Armonk.

Tezisy (1966). Abstracts of the presentations at the symposium "Method of modelling in natural science" (May 23-28, 1966) [in Russian] = Teзucbl 
докладов и выступлений на симпозиуме "Метод моделирования в естествознании” (23-24 мая 1966), Тартуский государственный университет, Тарту.

Valt, L. (1964). The Cognitive Importance of Thought Models in Physics [in Russian] = Вальт Л. О. Познавательное значение модельных представлений в физике (Уч. зап. Тартуского гос. ун-та, вып. 165. Труды по философиu, VIII), Тартуский госдарственный унивеситет, Тарту.

Valt, L. (1994). On the resistance of Estonian philosophy of science to the Communist Party ideology [in Estonian] = Eesti teadusfilosoofia vastuseisust parteiideoloogiale, in R. Vihalemm et al. (ed.), Teadusfilosoofia ja teadusmetodoloogia Eestis: olukord ja perspektiivid, Teaduslugu ja nüüdisaeg IX, TTEÜ ja TÜ filosoofia osakond, Tallinn, pp. 53-62.

Vihalemm, R. (1979a). On the problem of scientific theory in historical cognition [in Russian] = Вихалемм Р. О проблеме научной теории в историческом познании, Современные проблемы филосоофии истории: Тезисы докладов межвузовской научной конференции, 1618 апреля 1979 Tapmy, pp. 91-93.

Vihalemm, R. (1980). Concept of scientificity and social determination of the formation of a science (on the basis of the history of chemistry) [in Russian] = Вихалемм Р. Понятие научности и социальная детерминация формирования науки (на материале истории химии), in А. Б. Баженов and М. Д. Ахундов (eds), Наука в социальных, гносеологических и ценностных аспектах, Наука, pp. 345-358.

Vihalemm, R. (1981). The history of the formation of a science: On the development of chemistry [in Estonian] = Ühe teaduse kujunemislugu. Keemia arenguteest, Valgus, Tallinn.

Vihalemm, R. (1982). The dilemma of "aprioristic rationality" and "historiographic positivism" in the Western philosophy of science [in Russian] = Вихалемм Р. Дилемма "априорной рациональности” и "историографического позитивизма" в западной философии науки, Bonpocы философии 8: 55-65. [Summary in English, p. 174].

Vihalemm, R. (1983a). On the philosophical foundations of different programs concerning the rational reconstruction of the history of science, Logic, methodology and philosophy of science Papers of Soviet scientists adopted by the Soviet National organization committee for the VII International Congress on Logic, Methodology and Philosophy of Science, Institute of Philosophy of the USSR Academy of Sciences, Moscow, pp. 185-188.

Vihalemm, R. (1983b). On the problem of specificity of historical cognition 
(in the occasion of the paper by E. N. Loone) [in Russian] = Вихалемм P. К вопросу о специфике исторического познания (по поводу статьи Э. Н. Лооне), Tartu Ülikooli toimetised. Töid filosoofia alalt 653: 53-67.

Vihalemm, R. (2001a). Introduction: Estonian science studies, in R. Vihalemm (ed.), Estonian Studies in the History and Philosophy of Science, Kluwer Academic Publishers, Dodrecht, pp. vii-xiv.

Vihalemm, R. (2001b). Philosophy of science in Estonia: The background and the situation of today, Historiae Scientarium Baltica, Abstracts of XX Baltic Conference on the History of Science, pp. 45-46.

Vihalemm, R. (2006). On the conception of the practical nature of science: Reflecting on the development of philosophy of science in Estonia, Historia Scientarium Baltica, Abstracts of XXII Baltic Conference on the History of Science, pp. 116-117.

Vihalemm, R. (2008). Theoretical philosophy and philosophy of science in the Soviet times: Some remarks on the example of Estonia in 1960-1990, in J. Stradinš and A. Zigmunde (eds), Nova Miscellanea Historia Scientiarum Baltica 50, RTU Publishing House, Riga, pp. 23-24.

Vihalemm, R. (ed.) (1979b). Methodology of science [in Estonian] = Teaduse metodoloogia, Eesti Raamat, Tallinn.

Vihalemm, R. and Müürsepp, P. (2007). Philosophy of science in Estonia, Journal for General Philosophy of Science 38: 167-191.

Vihalemm, R. and Näpinen, L. (1986). On dialectical nature of synergetic theories (philosophical meaning of studies of I. Prigogine's school) [in Russian] = Вихалемм Р., Няпинен Л. О диалектической природе синергетических теорий (философское значение исследований школы И. Пригожина), Tartu Ülikooli toimetised. Töid filosoofia alalt 731: $108-124$.

Vihalemm, R. and Näpinen, L. (1987). The principle of historicity in I. Prigogine's scientific programme (on contradiction between classical scientific world picture and historical reality) [in Russian] = Вихалемм Р., Няпинен Л. Принцип историзма в научной программе И. Пригожина (о противоречии между классической научной картиной мира и исторической действительностью, Tartu Ülikooli toimetised. Töid filosoofia alalt 786: 24-38.

Wartofsky, M. W. (1979). Models: Representation and the Scientific Understanding, Reidel, Dordrecht.

Zweerde, E. v. d. (1997). Soviet Historiography of Philosophy: Istorikofilosofskaja Nauka, Kluwer Academic Publishers, Boston. 